\title{
Peran Kepemimpinan Misi Paulus dan Implikasinya bagi Pemimpin Misi Masa Kini
}

\author{
Christian Bayu Prakoso \& Yonatan Alex Arifianto
}

\begin{abstract}
Abstrak
Gereja pada zaman ini mulai kehilangan esensi dan tujuan utamanya untuk memberitakan Injil. Salah satu faktor yang menyebabkan gereja kurang optimal dalam pemberitaan Injil adalah lemahnya kepemimpinan misi yang dimiliki. Kepemimpinan misi adalah kemampuan seseorang untuk mempengaruhi dan menggerakkan orang supaya terlibat aktif dalam misi Allah. Salah satu tokoh besar dalam kegerakan misi di dunia adalah Rasul Paulus. Oleh sebab itu, penelitian ini bertujuan untuk mengetahui karakter kepemimpinan misi yang dilakukan oleh Paulus dan implikasinya bagi pemimpin pada masa kini. Hasil dari penelitian ini adalah adanya tiga prinsip kepemimpinan misi Paulus yang dapat diimplikasikan bagi pemimpin masa kini, yaitu: pertama, menjadi pelaku yang aktif bermisi dalam mengandalkan Tuhan; kedua, mendidik petobat baru dan mencetak pemimpin misi. Dan ketiga, mengutus dan menguatkan misionari untuk menghadapi tantangan di tempat pelayanan.
\end{abstract}

Kata Kunci: kepemimpinan misi, implikasi, pemimpin, Amanat Agung

\begin{abstract}
The church today begins to lose the essence and main purpose of preaching the gospel. One of the factors that causes the church less effective in preaching the gospel is the weakness of its mission leadership. Mission leadership is a person's ability to influence and mobilize people who are involved in God's mission. One of the great figures in the missionary movement in the world was the Apostle Paul. Therefore, this study aims to see the character of mission leadership carried out by Paul and connected to the implications for leaders on current missions. The results of this study are the existence of three principles of Paul's mission leadership that can be implicated for today's leaders, namely: first, to be an active actor in relying on mission; secondly, to educate new converts and to produce mission leaders. And thirdly, send and strengthen missionaries to meet challenges in the place of service. Keywords: mission leadership, implication, leader, Paul
\end{abstract}

\section{Pendahuluan}

Kepemimpinan Memberitakan Injil dalam menjalankan mandat Amanat Agung Yesus Kristus adalah tugas bagi semua orang percaya yang telah menerima keselamatan dari Yesus Kristus secara pribadi, dan menyadari bahwa Allah bekerja sama dengan 
orang percaya sebagai bagian dari kawan sekerja-Nya dengan tujuan membawa kabar baik atau Injil keselamatan bagi mereka yang belum pernah mendengar karya keselamatan Yesus Kristus. Dalam penginjilan dibutuhkan kepemimpinan misi supaya dapat mengkoordinasi jalannya keberlangsungan misi itu. Kepemimpinan misi adalah kemampuan dari seorang pemimpin gereja yang mampu mempengaruhi orang lain melalui inspirasi Allah untuk terlibat dalam pengabaran Injil bagi seluruh dunia. Dan kemampuan seseorang adalah bagaimana cara untuk mempengaruhi orang lain. ${ }^{152}$ Sedangkan misi sejatinya tidak dapat dilepaskan dari peran Allah dan penyataan diri Allah sebagai Dia yang mengasihi dunia, keterlibatan Allah di dalam dan dengan dunia, sifat dan kegiatan Allah, yang merangkul gereja dan dunia serta tempat gereja mendapatkan kesempatan istimewa untuk ikut serta. ${ }^{153}$ Oleh sebab itu misi lebih merujuk kepada aktivitas gereja untuk terlibat dan berkarya dalam rencana Allah akan dunia ini.

Memberitakan Injil dalam menjalankan mandat Amanat Agung Yesus Kristus adalah tugas bagi semua orang percaya yang telah menerima keselamatan dari Yesus Kristus secara pribadi, dan menyadari bahwa Allah bekerja sama dengan orang percaya sebagai bagian dari kawan sekerja-Nya dengan tujuan membawa kabar baik atau Injil keselamatan bagi mereka yang belum pernah mendengar karya keselamatan Yesus Kristus. Sebab penginjilan harus dilaksanakan dengan segala upaya termasuk kepemimpinan dalam misi sebagai tugas dan kewajiban orang Kristen untuk memberitakan Injil Yesus. ${ }^{154}$ Namun kenyataannya, banyak gereja yang mulai kehilangan fungsi misi oleh karena lemahnya kepemimpinan yang berorientasi pada misi.

Berdasarkan survei yang dilakukan oleh Bilangan Research Indonesia tentang pemahaman pemimpin gereja terhadap Amanat Agung, didapatkan hasil sebesar 16,7 persen pendeta dan gembala sidang tidak memahami arti dari amanat agung. ${ }^{155}$ Hasil survei di atas membuktikan bahwa tidak semua pemimpin gereja memiliki pemahaman yang baik atas tugas utama sebuah gereja, yaitu penginjilan. Sebab salah satu perintah Tuhan Yesus yang harus ditaati dan dilakukan oleh setiap orang percaya adalah Amanat Agung yang terus dipertahankan orang-orang Kristen sampai saat ini. Tidak sedikit

152 J. Oswald Sanders, Kepemimpinan Rohani (Bandung: Yayasan Kalam Hidup, 1993), 19.

${ }^{153}$ David J. Bosch, Transformasi Misi Kristen (Jakarta: BPK Gunung Mulia, 1997), 15.

${ }^{154}$ Tumpal H Hutahaean, "Signifikansi Apologetika Dalam Penginjilan," STULOS, 2019.

${ }^{155}$ Bilangan Research Indonesia, Survey Amanat Agung : Sudahkah Memudar? (Jakarta: Yayasan Bilangan Research Center, 2019), 31. 
gereja-gereja yang mengerahkan kekuatannya untuk melaksanakan Amanat Agung dengan berbagai cara yang kreatif dan kekinian. Namun fenomena yang ada, seringkali Amanat Agung dijalankan sebagai suatu program atau proses "pemberitaan", yang cenderung menekankan "pergi" berpindah dari satu tempat ke tempat lainnya. ${ }^{156}$ Dalam praktek bermisi, keterlibatan orang-orang percaya dan gereja-gereja masih jauh dari yang diharapkan. Ada saja penghalang yang menghambat berjalannya pekerjaan misi ini. Alasan klasik yang dikemukakan adalah perasaan sebagai minoritas menghinggapi orang percaya di negara-negara berkembang, seperti juga di Indonesia. ${ }^{157}$

Membahas tentang misi dan gereja, salah satu tokoh dalam Alkitab yang berbicara banyak tentang hal itu tidak lain adalah Rasul Paulus. Paulus adalah tokoh yang memiliki andil besar dalam pemberitaan Injil ke seluruh dunia. Semangat dan perjuangannya untuk memberitakan Injil hampir mendominasi sebagian besar kitab yang ada dalam Perjanjian Baru, tanpa mengecilkan peran dan kontribusi tokoh-tokoh lainnya. Hal tersebut dibuktikan oleh banyaknya buku yang menulis tentang Paulus dan pelayanan misi. David J. Bosch dalam bukunya Tranformasi Misi mengutip tulisan dari Paul Werle demikian, satu jawaban kepada pertanyaan tentang siapa dia (Paulus) dadalah seorang rasul Yesus Kristus, seorang misionaris. ${ }^{158}$

\section{METODE}

Pendekatan penulisan yang digunakan dalam penelitian ini adalah penelitian pustaka dengan pendekatan kualitatif deskriptif. ${ }^{159}$ Untuk dapat memaparkan tentang peran kepemimpinan misi Paulus dan implikasinya bagi pemimpin misi masa kini maka penulis melakukan studi pustaka terhadap berbagai sumber literatur serupa jurnal teologi ataupun buku-buku yang sesuai dengan tema, sehingga diperoleh gambaran peran kepemimpinan misi Paulus. Dalam proses penelitian ini, maka langkah pertama,

${ }^{156}$ Patrecia Hutagalung, "Pemuridan Sebagai Mandat Misi Menurut Matius 28:18-20," Pengarah: Jurnal Teologi Kristen, 2020, https://doi.org/10.36270/pengarah.v2i1.22.

${ }^{157}$ Darsono Ambarita, Perspektif Misi Dalam Perjanjian Lama Dan Perjanjian Baru (Medan: Pelita Kebenaran Press, 2018).

158 Bosch, Transformasi Misi Kristen, 56.

${ }^{159}$ Sonny Eli Zaluchu, "Strategi Penelitian Kualitatif Dan Kuantitatif Di Dalam Penelitian Agama," Evangelikal: Jurnal Teologi Injili Dan Pembinaan Warga Jemaat, 2020, https://doi.org/10.46445/ejti.v4i1.167. 
penulis berusaha menggali aspek-aspek dalam kepemimpinan misi. Kemudian, penulis menggali kehidupan Paulus dalam menerapkan praktik kepemimpinan misi.

Terakhir, penulis akan memberikan implikasi kepemimpinan misi Paulus bagi pemimpin masa kini. Penulis akan memanfaatkan berbagai sumber, seperti Alkitab, buku, jurnal, tafsiran, dan artikel ilmiah untuk mendapatkan data yang lengkap. Hal tersebut dilakukan untuk memperkaya kajian yang dilakukan oleh penulis. Lalu yang terakhir penulis memberikan saran bahwa misi sebagai bagian dari gaya hidup yang disertai dengan implikasi untuk orang percaya masa kini. Dengan hal itu pemimpin harus memfokuskan doa dan terlibat secara aktif dalam melaksanakan misi; pemimpin gereja wajib melakukan pekabaran Injil dengan menyampaikan pesan Injil dengan jelas dan terlebih pemimpin mempersiapkan kelompok kecil untuk pemuridan sebagai pembekalan dalam mempersiapkan misionaris untuk terjun dalam ladang pelayanan.

\section{PEMBAHASAN}

\section{Misi dan Kepemimpinan Misi}

Pengertian misi atau penginjilan dapat dipahami sebagai: Satu tugas untuk mengumumkan atau memberitakan kabar baik, dan atau kabar keselamatan di dalam Yesus Kristus. Tugas tersebut dilakukan dengan cara menyerukannya seperti seorang utusan raja yang sedang mengumumkan satu dekrit, yaitu dengan suara yang keras dan tegas, dan dapat juga dilakukan dengan mengajar seperti kepada seorang murid, dan dengan bersaksi berdasarkan apa yang dialami oleh pemberita Injil tersebut. ${ }^{160}$ Pekerjaan memberitakan Injil atau kabar baik adalah inisiatif dan karya pekerjaan Tuhan. Namun Tuhan memerlukan kerja sama dengan manusia ini berarti orang percaya memiliki tugas ganda, yaitu melakukan tugas pelayanan yang dipercayakan kepadanya dengan baik, tetapi di pihak lain, juga harus bertanggung jawab memproklamasikan kabar baik tentang Yesus Kristus. Paulus merupakan pelaku misi, yang berarti ia melakukan pemberitaan Injil itu kepada semua orang. Kis 13:2 berbunyi, pada suatu hari ketika mereka beribadah kepada Tuhan dan berpuasa, berkatalah Roh Kudus: "Khususkanlah Barnabas dan Saulus bagi-Ku untuk tugas yang telah Kutentukan bagi mereka." Kemudian mereka pergi memberitakan Injil. Namun demikian, tidak hanya pergi memberitakan Injil, Paulus juga memperkuat dan memberdayakan

${ }^{160}$ Djuwansah Suhendro P Stephanus, "Mengajarkan Penginjilan Sebagai Gaya Hidup Orang Percaya," Redominate, 2019. 
orang lain untuk melakukan apa yang ia lakukan. Paulus mengutus Timotius, Titus, Erastus, dan beberapa orang lainnya untuk menggembalakan sidang jemaat di berbagai kota untuk mewakili dia. Berdasarkan pemaparan di atas, penulis tergerak untuk membuat kajian tentang kepemimpinan misi yang diterapkan oleh Paulus dalam pelayanannya, supaya dapat diimplikasikan terhadap pemimpin misi pada masa kini.

Ada empat istilah yang paralel dalam bahasa Yunani yang digunakan untuk menyatakan tentang penginjilan: euangelizo artinya mengabarkan Injil atau kabar baik, kerusso artinya berkhotbah atau memproklamirkan, didasko artinya mengajar dan martureo artinya bersaksi. ${ }^{161}$ Seperti yang disampaikan oleh Schnabel bahwa: Kata dari Penginjilan dalam Perjanjian Baru menggunakan kata Yunani dengan kata "euangeliso," "euangelion", "euangelizomai" dan "euangelisastai." Memiliki arti pertama, memberitakan kabar baik "announce good news" (Lukas 1:19; Wahyu 14:6). Kedua, menyatakan atau berkhotbah tentang Injil "Proclaim, preach the gospel," (Luk 4:43; Kis 13:32; Roma 15:20; 1 Korintus 15:1; 2 Korintus 10:16; Gal 1:11, 23; 1 Petrus 1:12). Ketiga, mengabarkan kabar baik "have good news atau the gospel preached to one" Matius 11:5; Ibrani 4:2, 6 (evangelize). ${ }^{162}$ Oleh sebab itu pesan untuk mencari jiwa atau bermisi dimasukkan ke dalam teks Amanat Agung dan dijadikan teks untuk pekabaran Injil sebagai bagian dari motivasi dan panggilan sebagai orang percaya yang terlebih dahulu diselamatkan. Pesan penting dalam Amanat Agung (Matius 28:19-20), adalah mandat yang wajib dikerjakan sebagai bagian rencana Allah untuk keselamatan bagi dunia. Sejatinya misi gereja atau orang percaya secara personal tidak bisa dipisahkan dari Amanat Agung Tuhan Yesus. Dan yang pasti Amanat Agung tersebut berkaitan dengan tanggung jawab untuk bermisi. ${ }^{163}$

Peters menyatakan bahwa perintah Tuhan dalam Amanat Agung memiliki tujuan dan konsep antara lain: yang pertama adalah Amanat Agung merupakan suatu penyajian terakhir yang logis dan merupakan ekspresi alami dari karakter Allah, seperti diwahyukan dalam Alkitab bahwa Ia mengasihi manusia. Kedua, ekspresi dari maksud serta tujuan misioner Allah, ekspresi dari kehidupan, teologi, dan karya keselamatan Kristus yang harus dikerjakan oleh Yesus. Ketiga, ekspresi dari sifat dan pekerjaan Roh

161 Yakob Tomatala, Penginjilan Masa Kini 2 (Malang: Gandum Mas, 2018).

${ }^{162}$ Eckhard J. Schnabel, Paul The Missionary (Downers Grove: InterVarsity, 2008).

${ }^{163}$ Kosma Manurung, "Efektivitas Misi Penginjilan Dalam Meningkatkan Pertumbuhan Gereja," DUNAMIS: Jurnal Teologi Dan Pendidikan Kristiani 4, no. 2 (2020): 225-33, https://doi.org/10.30648/dun.v4i2.242. 
Kudus dan ekspresi dari hakikat dan rencana dari gereja Yesus Kristus. Empat, membentuk kesatuan organik serta merupakan bagian tak terpisahkan dari ketiga penyataan di atas. ${ }^{164}$ Sedangkan Tomatala menjelaskan Amanat agung berdasarkan etimologi bahwa istilah misi berasal dari bahasa latin missio yang diangkat dari kata dasar mittere, yang berkaitan dengan kata missum, yang artinya mengirim atau mengutus yang harus dikerjakan. ${ }^{165}$ Padanan kata ini dalam bahasa Yunani ialah aposttelo, yang berarti mengirim dengan otoritas. ${ }^{166}$ Oleh karena Allah sendiri sebagai sumber misi maka jelaslah jika landasan bagi rencana Allah yang kekal ini beranjak dari hati-Nya, dan Ia berinisiatif untuk melaksanakan misi-Nya.167 Pelaksanaan misi itu ditunjang oleh kekuatan dan kuasa-Nya guna mencapai misi tersebut. ${ }^{168}$ Sebab intinya bahwa Amanat Agung yang di dalamnya terdapat nilai misi memaparkan tujuan utama sebagai prioritas memenangkan jiwa. ${ }^{169}$ Dan juga misi biasanya selalu disamakan dengan kerinduan Allah yang bekerjasama dengan manusia bahwa Allah ada untuk dunia. ${ }^{170}$

Perlu disadari bahwa pemberitaan Injil hanyalah salah satu dari banyak langkah dalam proses penginjilan, dan bukan tahap yang pertama. Hal-hal lain perlu dilakukan, seperti membajak atau mencangkul, membersihkan rumput liar, menaburkan benih, dan menyiram, di mana semuanya pasti membutuhkan waktu. ${ }^{171}$ Dalam pelayanan penginjilan baik yang dilakukan oleh Yesus dan Paulus selain terjun langsung dalam misi tersebut namun juga memberikan arahan terhadap murid-murid-Nya. Karena itu kepemimpinan misi menjadi penting dalam melakukan misi secara korporat. Kepemimpinan misi lebih luas dari hanya sekedar memberitakan Injil dari rumah ke rumah, kota ke kota, ataupun sampai lintas negara. Seringkali, seorang pimpinan lembaga misi, pendeta atau gembala sidang merasa puas ketika sudah menjangkau dan memenangkan jiwa. Namun, terlebih dari semua itu seorang pemimpin misi dalam sebuah organisasi harus mampu menggerakkan orang lain untuk juga memiliki yang

${ }^{164}$ George W. Peters, A Biblical Theology of Missions (Malang: Gandum Mas, 2006).

165 Yakob Tomatala, Teologi Misi (Jakarta: YT Leadership Foundation, 2003).

${ }^{166}$ David J. Bosch, Tranformasi Misi Kristen (Jakarta: BPK Gunung Mulia, 1998).

${ }^{167}$ Stephen Tong, Teologi Penginjilan (Surabaya: Momentum, 2004).

168 Tomatala, Penginjilan Masa Kini 2.

${ }^{169}$ Bosch, Tranformasi Misi Kristen.

${ }^{170}$ Fernando Tambunan, "Tantangan Misi Dalam Prespektif Pemikiran Era Postmodern," in Seminar Mission Today, 2017, https://doi.org/10.1017/CBO9781107415324.004.

${ }^{171}$ MacDonald William, Penginjilan Pribadi, Buku 1 Dari Seri: Pedoman-Pedoman Praktis Bagi Orang Kristen (Jakarta: Sastra Hidup Indonesia, 2013). 
sama dalam memberitakan Injil. Keterlibatan jemaat dalam pelayanan misi secara alami harus menjadi dasar atau pola hidup dalam sebuah gereja atau organisasi misi. ${ }^{172}$

Sejarah salah satu denominasi gereja di Indonesia yaitu Gereja Baptis Indonesia di bawah naungan Gabungan Gereja Baptis Indonesia (GGBI) diawali dari datangnya 3 misionaris yang dikirim oleh Foreign Mission Board of The Southern Baptist Convention dari Amerika. Melalui pelayanan para misionaris, lahirlah orang-orang yang percaya kepada Yesus yang berpusat di Pulau Jawa. PadatTahun 1967 dan awal 1968, muncul beberapa keresahan berkaitan dengan ketidakjelasan rencana misi untuk mengembangkan gereja. Kemudian, pada November 1967, Badan Misi mengadakan konferensi misi untuk pengembangan gereja Baptis di Indonesia. Hasilnya, R. Keith Parks memberikan ringkasan metode misi efektif serta membentuk Badan Kerja Sama (BKS) yang berisikan sembilan gereja baptis dan lima orang misionaris yang memiliki tugas untuk merencanakan dan merealisasikan program pewartaan Injil, pengembangan gereja-gereja dan riset, serta mempersiapkan pemimpin-pemimpin baru. ${ }^{173}$

Menurut Mays, beberapa bidang atau aspek dasar dalam kepemimpinan misi yang dirangkum penulis untuk memperkuat paper ini adalah berdoa yang berarti mengandalkan Tuhan dan aktif menjadi pelaku misi; merekrut dan mendidik orang lain untuk menjadi pemimpin jemaat; serta mengutus dan menguatkan misionari untuk menghadapi tantangan di tempat pelayanan. ${ }^{174}$ Aspek tersebut merupakan aspek dasar dari kepemimpinan misi, tanpa mengesampingkan beberapa aspek lain yang sifatnya spesifik dan cenderung teknis. Seorang pemimpin misi yang mampu melakukan hal-hal di atas, diyakini mampu menghasilkan orang-orang yang memiliki kerinduan untuk terlibat dan dipakai Tuhan menjadi alat-Nya.

\section{Paulus dan Praktik Kepemimpinan Misi}

Paulus adalah seorang Yahudi yang mengalami Helenisasi. Sebagai orang Yahudi, ia mengalami masa perubahan kultural, ketika kebudayaan termasuk pola hidup Yunani mendominasi seluruh dunia. Dalam Kisah Para Rasul 22:3 dijelaskan bahwa Paulus lahir di Tarsis, sebuah kota di pesisir Provinsi Kilikia. Paulus berasal dari keluarga Yahudi yang

172 David Mays, Bagaimana Membuat Jemaat Anda Terlibat Dalam Misi Penginjilan (Peachtree City: ACMC, 1997), 36.

173 Avery T. Wilis, Indonesia Revival (Bandung: Lembaga Literatur Baptis, 1977), 222-23.

${ }^{174}$ David Mays, Bagaimana Menjalankan Tim Kepemimpinan Misi Yang Efektif Di Gereja Anda (Peachtree City: ACMC, 1996). 
taat beribadah dan menjadi bagian dari gerakan Farisi (Galatia 1:13-14; Filipi 3:5-6).175 Paulus adalah orang yang menganiaya pengikut Kristus dan berusaha membunuhnya. Perubahan dirinya menjadi seorang Rasul besar dimulai dari peristiwa pertobatan dan pemanggilannya. Dalam perjalanannya dari Yerusalem ke Damsyik, ketika ia ingin menangkap orang yang percaya kepada Yesus, ia mengalami perjumpaan pribadi dengan Yesus (Kis. 9:1-19). Peristiwa tersebut merupakan titik awal Paulus berubah menjadi seorang pengikut Kristus bahkan rela mati untuk Kristus. Karena bagi Paulus pengalaman tersebut membuatnya bergairah untuk membawa manusia yang memiliki kebutuhan yang bersifat sosial dan spiritual, seperti yang dialaminya, agar melalui Injil yang diberitakan kebutuhan-kebutuhan tersebut terjawab. Bahkan Injil mampu memberikan dampak yang sangat signifikan bagi setiap orang yang mau menerimanya. ${ }^{176}$

Pemahaman Rasul Paulus tentang misi bukanlah suatu bangunan abstrak yang bergantung pada sebuah prinsip universal, melainkan suatu analisis tentang realitas yang didorong oleh suatu pengalaman mula-mula yang memberikan Paulus sebuah pandangan dunia yang baru. ${ }^{177}$ Artinya, pelayanan misi Paulus bukanlah sebuah rancangan metode yang kaku dan terikat layaknya rencana perusahaan atau bisnis pada umumnya. Pengalaman perjumpaan pribadi dirinya dengan Yesuslah yang menjadi dasar. Jika melihat metode fleksibel yang digunakan di bawah kepemimpinan Roh Kudus dan tunduk pada petunjuk dan kontrol-Nya, Paulus memang memiliki pola yang khas. ${ }^{178}$ Pernyataan Kane dilontarkan secara implisit namun menohok. Ia ingin menunjukkan bahwa perjumpaan pribadi Paulus dengan Dia dan kepekaan terhadap suara Roh Kudus mengalahkan semua metode yang diciptakan oleh manusia. Sebab Roh Kudus memberikan hikmat dan pengertian untuk mengenal Yesus dan menghayati-Nya di setiap langkah perjalanan hidup. Dan juga Roh Kudus menuntun kepada seluruh kebenaran Allah, sehingga orang yang dituntun-Nya terhindar dari penyesatan. ${ }^{179}$ Terdapat sebuah

${ }^{175}$ Eckhard J. Schnabel, Rasul Paulus Sang Misionaris: Perjalanan, Strategi, Dan Metode Misi Rasul Paulus (ANDI: Yogyakarta, 2008), 26.

${ }^{176}$ David Eko Setiawan, "Dampak Injil Bagi Transformasi Spiritual Dan Sosial," BIA': Jurnal Teologi Dan Pendidikan Kristen Kontekstual 2, no. 1 (2019): 83-93.

177 Senio Donald, The Foundations for Mission in Teh New Testament (Maryknoll, New York: Orbis Books, 1983), 171.

178 J. Herbert Kane, Christian Missions in Biblical Perspective (Grand Rapids: Baker Book House, 1976), 73.

${ }^{179}$ Yonatan Alex Arifianto and Asih sumiwi Rachmani, "Peran Roh Kudus Dalam Menuntun Orang Percaya Kepada Seluruh Kebenaran Berdasarkan Yohanes 16 : 13," Jurnal Diegesis 3, no. 1 (2020): 1-12. 
poin utama yang didapatkan di dalam riwayat kehidupan Paulus. Ketergantungan dengan Tuhan adalah kunci utama untuk melakukan pekerjaan kepemimpinan misi.

Adapun tiga aspek kepemimpinan misi yang dilakukan oleh Rasul Paulus adalah sebagai berikut :

\section{Menjadi pelaku yang aktif bermisi dalam mengandalkan Tuhan}

Rasul Paulus adalah pribadi yang memiliki keaktifan dalam menjalankan tugas misi dilihat dari perjalanan pertama dan ketiga tentang misi ke Asia Kecil. Dalam menjadi pelaku misi Paulus selalu mengandalkan Tuhan sebab melalui pengandalan kepada Tuhan melalui doa merupakan batu bangunan dalam segala perencanaan karena doa memberikan perspektif mengenai siapa yang berkuasa dan sebuah alat yang dipakai Allah untuk mengubah kita. ${ }^{180}$ Dalam setiap pelayanan pengabaran Injil, Paulus senantiasa berdoa kepada Tuhan. Sebelum Paulus dan Barnabas pergi untuk memberitakan Injil, mereka berdoa dan berpuasa (Kis. 13:2-3). Kemudian Paulus berkeliling memberitakan Injil dengan penuh semangat tanpa ketakutan sedikit pun. Pada kisah hidup lainnya, ketika Paulus bersama Silas berada di dalam penjara di Filipi, ia tetap berdoa dan menyanyikan puji-pujian kepada Allah (Kis. 16:25). Padahal pada waktu itu, mereka sedang mengalami penyiksaan yang luar biasa. Bahkan mereka bernyanyi hingga tahanan lain mendengarkan mereka bernyanyi. Hal itu membuktikan, bahwa dalam situasi apapun Rasul Paulus tetap mengandalkan Tuhan dan berani memberitakan Injil Tuhan.

Paulus memberitakan Injil di berbagai tempat, seperti sinagoge, ruang kuliah tirani, pasar, dan rumah pribadi. ${ }^{181}$ Artinya di mana pun ia berada, ia terus memberitakan Injil. Kepemimpinan misi berbicara tentang keteladanan untuk terus mau bekerja dan melakukan tugas pemberitaan terlebih telibat aktif. Sebab yang dibutuhkan pemimpin rohani yang terpenting adalah darimana pemimpin mendapatkan dan menyampaikan visinya; karena visinya berasal dari pewahyuan Allah sendiri, karena hanya Allah sendiri yang menentukan agendanya. ${ }^{182}$ Pemimpin yang rindu jemaatnya untuk terus menjadi pelaku misi dan terlibat dalam kegerakan misi harus membangun hubungan

\footnotetext{
1987), 47.

${ }^{180}$ Paul Borthwick, Pemberitaan Injil, Tugas Siapa? (Bandung: Yayasan Kalam Hidup,

${ }^{181}$ Schnabel, Rasul Paulus Sang Misionaris: Perjalanan, Strategi, Dan Metode Misi Rasul Paulus.

${ }^{182}$ Henry and Richard Blackaby, Kepemimpinan Rohani (Batam: Gospel Press, 2005), 102.
} 
pengandalan akan Tuhan serta memiliki kemauan teguh secara pribadi untuk mengabarkan Kabar Baik. Dengan kata lain, seorang pemimpin harus memiliki integritas, dan apa yang disampaikan selaras dengan apa yang ia lakukan.

\section{Mendidik petobat baru dan mencetak pemimpin misi}

Dalam setiap perjalanannya, Rasul Paulus tidak hanya memberitakan Kabar Baik, namun juga mengajar dan mendidik mereka menjadi murid Kristus. Ketika orang-orang, baik Yahudi maupun Non-Yahudi bertobat dan beriman kepada Yesus oleh karena pelayanan Paulus dan rekan-rekanya, Paulus memerintahkan supaya mereka tetap berkumpul bersama untuk mendapat pengajaran dan menyembah. Artinya, Paulus tidak hanya berhenti pada tahap penginjilan, namun juga memuridkan. Melalui surat-surat yang ditulis oleh Paulus, dapat ditemukan adanya beberapa topik pengajaran yang Paulus berikan, yaitu tentang teologi, etis, kehidupan bergereja, dan pelayanan penginjilan. ${ }^{183}$ Orang Yahudi yang baru percaya kepada Yesus, perlu belajar cara tingkah laku baru, meninggalkan tradisi yang telah dianut selama bertahun-tahun. Kasus lebih spesifiknya adalah menghilangkan jarak antara Yahudi dan Non-Yahudi.

Paulus harus merubah mindset orang Yahudi yang selalu memandang rendah orang Yunani menjadi sebuah persekutuan yang baik. Paulus juga memberikan didikan dan semangat kepada beberapa orang untuk dapat dan mampu memberikan arahan kepada orang lainnya, Akwila dan Priskila rekan pelayanan Paulus. Akwila dan Priskila adalah sahabat yang dihormati oleh Paulus dan ketiganya melakukan pelayanan bersama, berkeliling memberitakan Injil sambil tetap menekuni pekerjaannya untuk membuat tenda. ${ }^{184}$ Pasangan ini merupakan penginjil keliling dan pemimpin gereja di jemaat-jemaat yang didirikan Paulus. ${ }^{185}$ Kisah Para Rasul 18 memberikan gambaran bagaimana Paulus mendidik Awkila dan Priskila, bahkan Paulus tinggal bersama mereka selama 18 bulan. Setiap hari Sabat Paulus berbicara dalam rumah ibadat dan berusaha meyakinkan orang-orang Yahudi dan orang-orang Yunani (Ayat 4).

Didikan dan pengajaran yang dilakukan Rasul Paulus kepada Awkila dan Priskila membuahkan hasil yang luar biasa. Ketika Paulus meninggalkan keduanya untuk

${ }^{183}$ Schnabel, Rasul Paulus Sang Misionaris: Perjalanan, Strategi, Dan Metode Misi Rasul Paulus.

${ }^{184}$ Marie Noël. Keller, Priscilla and Aquila: Paul's Coworkers in Christ Jesus. (Collegeville: Liturgical Press, 2010).

${ }^{185}$ Carol Meyers, Women in Scripture (Michigan: Eerdmans Publisihing Company, 2000). 
melanjutkan perjalanan misinya, datanglah Apolos dari Aleksandria yang juga merupakan seorang pekabar Injil. Ketika Apolos mengajar dengan berani di rumah ibadat, Awkila dan Priskila membawa dia ke rumah mereka dan menjelaskan dengan teliti tentang ajarannya. Banyak yang menafsirkan bahwa hal ini dikarenakan pengetahuan Apolos tentang Kristus sangat terbatas. Di ayat 25 disebutkan bahwa ia hanya mengetahui tentang baptisan Yohanes.

Gambaran di atas, didikan dan pengajaran Paulus berhasil membuahkan pemimpin jemaat baru yang akhirnya juga mampu mendidik orang lain. Paulus mendidik Awkila dan Priskila, kemudian Priskila dan Awkila mendidik Apolos. Sebuah rantai pemuridan yang sangat baik. Sejatinya ada banyak sekali rekan pelayanan Paulus yang dididik untuk menggembalakan jemaat lokal. Seperti dalam Kisah Para Rasul 6:7, berbunyi "Firman Allah makin tersebar, dan jumlah murid di Yerusalem makin bertambah banyak". Frasa ini menunjuk pada terjadinya proses seseorang yang membawa murid baru kepada Kristus dan kemudian membimbingnya mulai pertobatannya sampai menjadi seorang murid yang kokoh, berserah, mengabdi, berbuah, dan dewasa; dan pada suatu waktu dapat mengulangi proses itu dalam kehidupan orang lain. ${ }^{186}$ Marvin Leech mengatakan bahwa roda kehidupan murid Yesus bertujuan Christlike (Yoh. 15:5; Gal. 2:20). ${ }^{187}$

Mengutus dan menguatkan misionari untuk menghadapi tantangan di tempat pelayanan.

"Paulus adalah pemain tim." Ia jarang sekali melayani sendirian. ${ }^{188}$ Ia bukanlah seorang misionaris yang tertutup dan kaku dalam bergaul dengan orang lain. Ia adalah orang Farisi yang memiliki pengetahuan mumpuni dalam hukum-hukum agama Yahudi. Dalam Kisah Para Rasul 9:27-29, ia berbicara dan bersoal-jawab dengan orang-orang Yahudi yang berbahasa Yunani. Hal tersebut membuktikan bahwa ia adalah orang yang dapat menjalin relasi dan bekerjasama dengan orang lain. Ia adalah misionaris dengan kepribadian terbuka.

Secara singkat, perjalanan misi Rasul Paulus dibagi menjadi 3 bagian: Perjalanan misi yang pertama, Paulus melayani bersama Barnabas disertai Yohanes Markus (Kis.

${ }^{186}$ LeRoy Eims, Pemuridan Seni Yang Hilang (Bandung: Lembaga Literatur Baptis, 2002), 11.

${ }^{187}$ Marvin Leech, Pemuridan (Global Mission Center, 1997), 1-3.

188 The Johny, Menjadi Pemimpin Unggul Dengan Strategi Marketing Paulus (Yogyakarta: ANDI, 2006), 103. 
13:4-5). Perjalanan misi yang kedua, Paulus disertai oleh Silas (Kis. 15:40), Timotius (Kis. 16:3), dan Lukas (Kis. 16:10). Paulus juga bekerja-sama dengan Priskila dan Awkila. Bahkan ia tinggal serumah dan melayani bersama mereka di Korintus selama 18 bulan (Kis. 18:2-4,11). Dalam perjalanan misi yang ketiga, Paulus disertai Timotius dan Erastus (Kis. 19:22), Gayus dan Aristarkhus (Kis. 19:29), dan teman-teman lainnya. Dari gambaran di atas, dapat disimpulkan bahwa Paulus memiliki rekan-rekan dalam melayani Tuhan.

Ada beberapa pendapat tentang jenis atau macam rekan dari Paulus. Menurut Ollrog, tiga kategori rekan Paulus adalah pertama, kalangan yang paling akrab terdiri dari Barnabas, Silwanus, dan khususnya Timotius. Kedua, rekan-rekan sekerja yang independen seperti misalnya Priskila dan Awkila dan Titus. Ketiga, para wakil jemaat setempat, yaitu Epafroditus, Epafras, Aristharkus, Gayus dan Yason. ${ }^{189}$ Sedangkan menurut Jacobs, rekan pelayanan Paulus juga dikategorikan dalam tiga jenis, yaitu Pertama teman sejawat yang bukan merupakan pembantunya, seperti Barnabas, Silas, dan Apolos. Kedua, pembantu dan utusan, yang tidak hanya menemani Paulus tapi juga diberikan tugas khusus dan diutus untuk mewakili Paulus sendiri, seperti Timotius, Titus, Erastus, Tithikus, Onesimus, Eprafas, dan Epafroditus. Ketiga, teman seperjuangan yaitu orang-orang yang tidak diberi tugas atau diutus Paulus, tetapi menemani dan membantunya, baik secara spiritual maupun material. 190

Pemaparan di atas menunjukkan bahwa Paulus bekerja sama dengan banyak orang. Paulus menggambarkan dirinya dan rekan misinya sebagai "kawan sekerja Allah" (1 Kor. 3:9). Ungkapan tersebut mengandung makna bahwa Paulus dan setiap orang yang percaya kepada Kristus dipanggil untuk memberitakan Kabar Keselamatan. Pekabaran Injil bukanlah suatu hal yang ringan. Di dalam Alkitab, banyak sekali dicatat bahwa tugas pekerjaan Injil sangatlah berat (1 Tes 2:9 ; 2 Tes 3:8 ; 2 Kor 6:5). Istilah Yunani "kopos" menggambarkan "aktivitas yang berat", yaitu pekerjaan, kerja, dan kerja keras. Istilah tersebut merujuk kepada pekerjaan misi dan pekerjaan gereja setempat. ${ }^{191}$ Dengan tantangan itu Paulus tidak merasa berat hati maupun malu karena isi pemberitaannya adalah Kabar Baik tentang Yesus Kritus yang telah menyelamatkan hidupnya. ${ }^{192}$ Atas

${ }^{189}$ Bosch, Transformasi Misi Kristen.

190 Johny, Menjadi Pemimpin Unggul Dengan Strategi Marketing Paulus.

${ }^{191}$ Schnabel, Rasul Paulus Sang Misionaris: Perjalanan, Strategi, Dan Metode Misi Rasul Paulus.

${ }^{192}$ Alkitab Hidup Berkelimpahan Life Application Study Bible (Malang: Gandum Mas, 2016). 
dasar itulah, Paulus memerlukan rekan yang berfungsi sebagai penolong, penyemangat di kala dirinya mengalami tantangan. Ketika mengutus anak didiknya untuk melayani sebuah jemaat lokal, Paulus melakukan beberapa tugas kepemimpinan misi yang sungguh luar biasa bagi orang-orang yang diutusnya.

Ketika Rasul Paulus mengutus Timotius, ia mengerti benar karakter dan kepribadian Timotius. Paulus berjumpa dengan Timotius di Listra ketika dirinya melakukan perjalanan misi. Dalam Kisah Para Rasul 16:2 dikatakan ia dikenal baik oleh saudara-saudara di Listra dan di Ikonium. Frase "dikenal baik" membuktikan bahwa Timotius memiliki kepribadian yang baik di lingkungan masyarakat tempat ia tinggal. Paulus mengenal betul kepribadian Timotius. Paulus mengetahui jikalau Timotius adalah seorang muda yang cenderung pemalu (2 Tim. $1: 7 ; 1$ Tim. 4:12) dan memiliki gangguan kesehatan (1 Tim. 5:23). Selanjutnya, Paulus mendidik Timotius secara langsung. Ia meminta supaya Timotius menyertai dirinya dalam perjalanan. Timotius mengikuti semua ajaran, cara hidup, pendirian, iman, kesabaran, kasih dan ketekunan Paulus. Bahkan ia juga ikut menderita penganiayaan dan sengsara seperti yang Paulus alami (2 Tim. 3:10-11). Timotius benar-benar merasakan beratnya pelayanan sebagai seorang pemberita Injil.

Demikian juga dengan Titus, yang juga rekan sepelayanan Paulus. Paulus berjumpa dengan Titus ketika ia pergi dari Antiokhia ke Yerusalem pada 47 M. (Gal. 2:3). Pada akhir perjalanan misi Paulus, Titus tampil sebagai rekan sekerja yang bertanggung jawab untuk aspek praktis mengorganisasi pengumpulan dana untuk orang Kristen miskin di Yerusalem, yang telah dimulai Paulus untuk jemaat di Makedonia dan Akhaya. ${ }^{193}$

Paulus memberikan teladan dan mendelegasikan tugas kepada Titus. Artinya, Paulus benar-benar melibatkan langsung orang yang akan diutusnya. Dengan demikian, paradigma latihan untuk pelayanan misionaris yang dilakukan Paulus bersifat informal, dengan pelatihan dilakukan sengaja dalam kehidupan sehari-hari. Ketika Paulus mengutus Timotius untuk menggembalakan jemaat di Efesus, Timotius ditinggalkan Paulus di Efesus saat mereka sedang dalam perjalanan ke Makedonia (1 Timotius 1:3).194 Sebab Paulus menyaksikan timbulnya ajaran-ajaran sesat di dalam jemaat ketika ia

${ }^{193}$ Ollrog and Wolf Henning, Paulus Und Seine Mitarbeiter (Neukirchen-Vluyn: Neukirchener Verlag, 1979), 95.

${ }^{194}$ Merril C. Tenney, Survei Perjanjian Baru (Malang: Gandum Mas, 2009), 412. 
mengunjungi Kolose. Ajaran itu sangat berbahaya dan berpotensi untuk meruntuhkan iman jemaat di Efesus (2 Tim 3:13). Oleh sebab itu tugas berat diberikan Paulus kepada Timotius untuk melanjutkan pembinaan jemaat-jemaat, khususnya dalam menanggulangi ajaran-ajaran sesat. ${ }^{195}$ Sedangkan Paulus harus berangkat menuju ke Makedonia untuk mengutus Titus melayani jemaat yang ada di Kreta.

Motif Paulus meminta Titus untuk tinggal di Kreta dan menggembalakan jemaat di sana dilatarbelakangi oleh kacaunya situasi di Kreta. Gereja-gereja di Kreta tidak terorganisasi dan tingkah laku para anggotanya sangat ceroboh. ${ }^{196}$ Kerusuhan di Kreta disebabkan oleh gabungan dari kelemahan moral yang turun-temurun (Tit 1:12-13) dan perintah serta perkataan yang sia-sia yang disebarkan oleh penganut Yudaisme yang menyangkal Allah (1:16), tidak tertib (1:10), suka mengacau (1:1), dan mencari keuntungan sendiri (1:11). Berdasarkan pemaparan di atas, dapat ditarik kesimpulan bahwa Paulus mengutus anak didiknya untuk menggembalakan jemaat yang sedang memiliki persoalan. Bukan perkara yang ringan untuk melawan setiap ajaran-ajaran sesat yang ada. Namun, Paulus tetap percaya atas kemampuan Timotius dan Titus untuk mempertahankan Injil Kristus di Efesus dan Kreta.

Meskipun Rasul Paulus tidak sedang berada bersama-sama dengan jemaat ataupun Timotius, Titus dan lainnya, namun ia tetap setiap berdoa untuk orang-orang yang dikasihinya. Dalam 2 Tim. 1:3 dijelaskan bahwa Paulus mendoakan Timotius siang dan malam. Pada waktu Paulus menuliskan surat yang kedua terhadap Timotius, ia sedang berada di dalam Penjara Roma. Bahkan ia merasa bahwa umurnya tidak akan panjang lagi (2 Tim. 4:6).

Di tengah kondisinya yang begitu tersiksa, ia tetap berdoa untuk Timotius. Tidak hanya berdoa, Paulus juga memberikan motivasi kepada Timotius. Paulus mendorong Timotius untuk tetap menjaga kemurnian Injil di tengah ajaran-ajaran sesat yang berlangsung. Kuil-kuil dewi Artemis juga menjadi pusat percabulan dan kecemaran, tempat orang tidak malu-malu melakukan perbuatan seksual. ${ }^{197}$ Dalam Surat 2 Timotius dapat ditemukan beberapa motivasi yang diberikan Paulus kepada Timotius di antaranya jangan malu memberitakan Injil dan ikutlah menderita bagi Injil (1:8), memegang teguh ajaran Kristus $(1: 13,3: 14)$, berfokus kepada Kristus (2:4), dan bersabar menanggung

${ }^{195}$ R Budiman, Surat-Surat Pastoral I Dan II Timotius Dan Titus (Jakarta: BPK Gunung Mulia, 2008).

196 Tenney, Survei Perjanjian Baru.

${ }^{197}$ Adina Chapman, Pengantar Perjanjian Baru (Bandung: Yayasan Kalam Hidup, 1980), 83. 
beban (2:10). Paulus juga memberikan nasihat kepada Timotius berkaitan dengan cara menghadapi ajaran sesat. Dalam 2 Tim. 2:14-26 terdapat tiga cara untuk menghadapi ajaran sesat, yaitu menghindari omongan kosong yang tak suci yang hanya menambah kefasikan (ay. 16), menjauhi nafsu anak muda (Ayat. 22), menghindari soal-soal yang dicari-cari atau bodoh dan tidak layak (Ayat. 23). Paulus menekankan hal ini dengan tujuan supaya dalam diri Timotius tidak didapati kesalahan. Di samping itu, Paulus juga memerintahkan Timotius untuk segara mempersiapkan orang lain untuk memiliki kecakapan dalam mengajar. Artinya, Paulus berpikir jangka panjang dan mementingkan keberlanjutan pemberitaan Injil di Efesus. Paulus sungguh-sungguh memperhatikan utusannya, meskipun mereka terpisah jarak. Ia tetap berjuang supaya Injil dapat diberitakan lebih luas lagi.

\section{Implikasi Bagi Pemimpin Misi Masa Kini}

Kehidupan dasar gereja pada masa kini hendaknya tetap berpusat pada kehidupan gereja di zaman para rasul. Kehidupan dasar yang dimaksud adalah visi dan tujuan berdirinya gereja, yaitu menjadi saksi Kristus, karena sebuah gereja tanpa misi bukanlah gereja, dan orang-orang Kristen tanpa misi sesungguhnya bukanlah murid Yesus yang benar. ${ }^{198}$ Demikian juga dengan kepemimpinan Kristen dan segala motivasinya, seharusnya tidak dapat dilepaskan dari pemberitaan Injil sebagai tujuan akhir. Stephen Tong mengatakan motivasi yang benar dalam penginjilan memberikan kekuatan yang besar pada saat yang paling melelahkan, dan memberi keteguhan pada waktu aniaya menimpa, memberi sukacita pada waktu kesesakan menekan. ${ }^{199}$ Hannas dan Rinawaty menyatakan bahwa tantangan yang dihadapi dalam penginjilan, semestinya tidak mengendurkan orang Kristen, apalagi menghentikan aktivitas pemberitaan Kabar Baik. Sebaliknya, kesulitan, hambatan atau apa pun alasannya semestinya mendorong orang Kristen untuk berserah pada Allah dan tetap melakukan penginjilan. ${ }^{200}$ Sebab Ralph Winter, dari United States Center for World Mission (USCWM) atau pusat Misi Dunia Amerika Serikat memperkirakan bahwa kira-kira ada 12.000 kelompok masyarakat

198 Tim IPN, Blessed To Be A Blessing Course (Jakarta: Indonesian People Network, 2009), $\mathrm{X}-1$.

199 Tong, Teologi Penginjilan, 40.

${ }^{200}$ Hannas Rinawaty, "Menerapkan Model Penginjilan Pada Masa Kini," Kurios (Jurnal Teologi Dan Pendidikan Agama Kristen), 2019. 
belum terjangkau di dunia. ${ }^{201} \mathrm{Hal}$ itu juga terjadi di sebagian kecil dari suku atau kota yang ada di Indonesia. ${ }^{202}$ Didukung dengan fakta yang ada bahwa hal itu menunjukkan kepada gereja-gereja di Indonesia masih banyak orang yang belum mengenal Kristus. Bahkan masih banyak gereja yang tidak mengabarkan Injil. ${ }^{203}$

Hal itu karena banyaknya kepemimpinan gembala yang tidak melakukan sesuatu bagi penginjilan. Berbeda dengan kehidupan pemimpin di Tiongkok: pada tahun 1927 John Sung mulai mengadakan kebangunan rohani di Hinghwa. Dan selanjutnya Jhon Sung mengadakan penginjilan ke seluruh Tiongkok, dan pada tahun 1935 John Sung mulai mengadakan perjalanan ke luar negeri sampai ke negara Muangthai dan Serawak. ${ }^{204}$ Hal itu dilakukan untuk menyebarkan Injil bagi semua orang. Sebab pemimpin harus menjadi contoh dalam penginjilan, seperti yang diungkapkan Ron Jenson dan Jim Steven bahwa penginjilan merupakan pusat dari setiap pembicaraan dalam pertumbuhan dan kesehatan gereja. Gereja tidak akan pernah bertumbuh jika gereja tidak meneruskan pesan Tuhan Yesus untuk dunia. Dalam Kisah Para Rasul 1:8 penekanannya adalah pewartaan sampai ke ujung bumi. Penyebaran Injil ke luar dari tembok-tembok gereja adalah misi gereja. Bertumbuhnya gereja tergantung dari penyebaran Injil yang dilakukan oleh gereja. ${ }^{205}$

Karena itu berdasarkan hasil survei tentang kepemimpinan gereja yang kerap tidak menjadi teladan dan contoh dalam memberitakan Injil maka analisis tentang kepemimpinan misi Paulus, didapatkan beberapa implikasi berikut yang dapat menjadi pegangan dan pelaksana bagi pemimpin masa kini, di antaranya: pertama adalah berdoa dan terlibat aktif dalam pelaksanaan Injil. Ada sebuah kiasan atau "parikan" dalam bahasa Jawa yang berbunyi “Guru, digugu lan ditiru." Arti dari kiasan tersebut adalah seorang guru harus mampu menjadi penuntun dan teladan bagi para murid-muridnya. Demikian juga dengan kepemimpinan misi. Seseorang yang memimpin dalam bidang misi harus aktif terlibat dalam pekerjaan misi melalui doa dan pengabaran Injil secara pribadi. Doa merupakan pekerjaan utama pada masa menuai, karena Tuhan-lah yang empunya tuaian,

${ }^{201}$ Dean Wiebracht, Menjawab Tantangan Amanat Agung (Yogyakarta: Andi Offset, 2008), 14.

202 Daud Alfons, Pandie Nidia, and Lina Ardela, "URGENSI PENGINJILAN SEBAGAI TANGGUNG JAWAB GEREJA,” APOLONIUS : Jurnal Teologi Dan Pendidikan Kristen, 2020. 203 Alfons, Nidia, and Ardela.

${ }^{204}$ F. D Wellem, Riwayat Hidup Singkat Tokoh-Toko (Jakarta: BPK Gunung Mulia, 2003), 174.

205 Ron Jenson and Jim. Stevens, Dinamika Pertumbuhan Gereja (Malang: gandum mas, 2004), 241. 
mengawasi tuaian, dan menyediakan pekerjanya. ${ }^{206}$ Jemaat cenderung akan melihat keteladanan daripada apa yang diajarkan oleh pendeta atau hamba Tuhan.

Jemaat membutuhkan bukti keteladanan dari pemimpinnya. Apabila pemimpin tidak melakukan apa yang ia ajarkan, mustahil jemaat juga mau melakukan hal yang diajarkan. Dalam mendidik jemaat dalam kebenaran firman dan mencetak pemimpin baru, tugas seorang pendeta tidak hanya menjangkau orang, namun juga mendidik orang percaya untuk memiliki keteguhan di dalam Kristus. Ajaran tentang Alkitab harus disampaikan dengan jelas dan terang untuk menciptakan murid-murid yang teguh di dalam Tuhan. Salah satu tujuan utama sebuah gereja adalah pemuridan. Gereja ada untuk mendidik dan mengajar umat Allah. Pemuridan adalah proses untuk menolong orang menjadi lebih seperti Kristus dalam pikiran, perasaan, dan tindakan mereka. ${ }^{207}$ Sebab seorang pemberita Injil bukan hanya memahami inti berita Injil, tetapi juga harus hidup sesuai dengan kebenaran Injil.208 Teks Amanat Agung dalam Matius 28:18-20 juga menjelaskan bahwa tugas orang percaya tidak berhenti kepada menghasilkan petobat baru, melainkan menjadikan mereka murid. Pritz berkata nampaknya gereja abad XX tidak memfokuskan pemuridan dalam pikiran kita, melainkan tertarik kepada cara membuat jemaat terhibur. ${ }^{209}$ Pemimpin gereja tidak boleh mengabaikan tugas pemuridan ini.

Mempersiapkan pemimpin-pemimpin kelompok kecil adalah kunci untuk gereja dapat memuridkan lebih banyak orang. Paulus memilih Timotius dikarenakan ia dikenal baik oleh masyarakat Listra. Demikian juga Titus yang dipilih oleh karena pelayananya dalam mengatur keuangan yang baik. Pemimpin misi pada saat ini harus benar-benar memilih calon misionaris supaya tidak salah menempatkan orang dan berujung kepada kegagalan. Pengunduran diri misionaris dari ladang misi bukanlah hal yang baru ditemukan dalam pekerjaan misi di negara-negara seluruh dunia. 210

Adapun beberapa tahap seleksi yang dapat dilakukan dengan berbagai cara, salah satunya dengan menekankan aspek karakter, komitmen, kompetensi, dan budaya. Mempersiapkan misionaris berkaitan dengan latihan untuk pelayanan misionaris, beberapa ahli misiologi membedakannya menjadi empat bidang, yaitu karakter,

${ }^{206}$ Tom Wells, A Vision for Mission (Carlisle: Banner of Truth, 1985), 138.

${ }^{207}$ Rick Warren, Pertumbuhan Gereja Masa Kini (Malang: Gandum Mas, 1999), 112.

${ }^{208}$ Hutahaean, "Signifikansi Apologetika Dalam Penginjilan."

${ }^{209}$ Ronald Pritz, Kepemimpinan Kristen (Yogyakarta: STII, n.d.).

${ }^{210}$ Zach Bradley, The Sending Church Defined (Knoxville: Upstream Collective, 2015), 8. 
komitmen, kompetensi, dan budaya. ${ }^{211}$ Karakter dan komitmen adalah hal utama yang diperlukan untuk seorang misionaris. Memang pekerjaan pelayanan misi Paulus tidak sungguh-sungguh lintas budaya, seperti tidak perlu belajar bahasa, makna institusi atau simbol. Namun, pada zaman ini, pemimpin misi perlu untuk mempersiapkan calon misionaris dalam hal kebudayaan lokal tempat yang akan dituju. Hal itu disebabkan karena pada saat ini para calon misionaris telah bertumbuh dalam budaya tunggal, sehingga diperlukan adaptasi pembelajaran pandangan hidup, nilai-nilai, simbol-simbol, dan tingkah laku yang sesuai dengan kultur. Pelatihan misi ini semata-mata dilakukan supaya misionaris tidak kaget bahkan tertolak oleh masyarakat lokal.

Kepemimpinan misi Paulus juga memberikan dukungan doa dan motivasi terhadap misionaris. Tugas seorang pemimpin misi bukan berhenti sebatas mengutus misionaris pergi melintasi budaya, melainkan tetap memperhatikannya. Seorang pekerja misi lintas budaya, cenderung dan mudah terserang penyakit patah semangat. ${ }^{212}$ Oleh sebab itu, pemimpin harus tetap menjaga komunikasi dengan para misionaris. Pergumulan dan persoalan yang dihadapi oleh misionaris di lapangan harus senantiasa didukung melalui doa. Hal yang paling penting yang dapat didengar oleh seorang utusan Injil adalah, "Saya telah berdoa untuk Anda setiap hari." 213 Pada masa ini, pemimpin misi dapat mengajukan pertanyaan-pertanyaan tentang kondisi misionaris di lapangan. Borthwick memberikan lima pertanyaan yang dapat diajukan seperti tentang kehidupan sehari-hari, jangan terlalu sering menarik kesimpulan tentang pengabaran Injil, tentang kebutuhan keuangan, pokok doa bagi keluarga maupun pribadi, tentang kehidupan rohani, dan memberikan kata-kata yang membangun. ${ }^{214}$ Terlebih pemimpin misi juga harus mampu memberikan pertimbangan dan solusi ketika seorang misionaris yang diutus mengalami persoalan. Tidak dapat dipungkiri, misionaris tersebut adalah bagian tanggung jawab dari pemimpin misi yang mengutus. Pemimpin misi dapat berdiskusi dengan tim dan mencarikan solusi yang terbaik.

Pengalaman dari Don Everets dalam bukunya yang berjudul Go and Do menceritakan bahwa dirinya pernah mengalami pergumulan dalam menghadapi masalah

${ }^{211}$ Taylor David, Internationalizing of Missionaries (Grand Rapids: Baker Book House, 1991), 964-65.

${ }^{212}$ Neal Pirolo, 8 Kiat Jitu Pendukung Misionaris Profesional (Jakarta: OM Indonesia, 1997), 131.

${ }^{213}$ Borthwick, Pemberitaan Injil, Tugas Siapa?

${ }^{214}$ Borthwick. 
di lapangan. Orang-orang yang telah bertobat dan dimuridkan oleh misionaris yang diutus memiliki kerinduan untuk membuka panti asuhan. Tentu tujuan yang baik, namun masalahnya tidak ada cukup uang untuk melakukan hal tersebut. Bersama dengan temannya, Don Everest melihat keuangan gerejanya dan mengatakan "kita tidak dapat memakai uang gereja." Dia mengatakan pengambilan dari gereja adalah hal yang buruk karena tidak adanya kesinambungan. Akhirnya dia menemukan, ide lain yaitu dengan melatih dan memberikan modal jemaat setempat untuk membuat dan membuka toko kue di daerah itu. Kami seharusnya menambahkan "kaki" kepada "dudukan", bukan mengganti kaki-kaki tersebut menjadi kaki besar, tulis Don Everest. ${ }^{215}$

\section{KESIMPULAN}

Kepimpinan misi secara singkat berbicara tentang kemampuan untuk mempengaruhi orang lain dengan tujuan untuk terlibat dalam misi Allah (Missio Dei). Kepemimpinan misi tidak hanya berbicara tentang mengabarkan Injil, melainkan berusaha membuat lebih banyak orang untuk terlibat di dalamnya. Keteladanan Paulus dalam kepemimpinan misi yang dapat diimplikasikan bagi pemimpin masa kini adalah pertama: menjadi pelaku yang aktif bermisi dengan mengandalkan Tuhan, sebab cara tersebut adalah bagian dari keterbatasan manusia dalam kemampuan menginjilnya, sehingga diharapkan para pemimpin gereja dapat menjadi pemimpin misi yang selalu terus mengandalkan Tuhan dalam setiap langkah misi yang dijalankan. Kedua, Mendidik petobat baru dan mencetak pemimpin misi. Pola ini juga banyak dilakukan oleh para pemimpin misi dengan jemaat yang bertumbuh dan hal itu dilakukan supaya regenerasi misi terus berlanjut. Dan ketiga, Mengutus dan menguatkan misionari untuk menghadapi tantangan di tempat pelayanan. Gereja sejatinya adalah pendukung utama misi di manapun misionari ditempatkan. Peran gereja terlebih kepada pemimpin dapat mendorong dan terus memotivasi mereka di saat lemah dan mencukupkan segala kebutuhan misi sebagai tanggung jawab moral terlebih juga ketika mereka mengutus dan menjadikan misionari sebagai pembawa Kabar Baik ada pendampingan sebagai bagian dari kawan sekerja Allah dalam Tubuh Kristus.

Oleh sebab itu salah satu karakteristik yang harus dimiliki gereja lokal untuk mendukung pertumbuhan jemaat secara kuantitas adalah empowering leadership yang

${ }^{215}$ Don Everest, Go and Do (Jakarta: Literatur Perkantas, 2012), 232. 
menonjolkan sifat memperkuat dan memberdayakan orang lain yang dipimpin. Tidak dapat dipungkiri bahwa kepemimpinan misi merupakan faktor dominan yang mempengaruhi gereja untuk meresponi Amanat Agung Kristus dengan tujuan memuridkan bangsa-bangsa. ${ }^{216}$ Seorang pemimpin perlu menguatkan dan memberdayakan jemaat untuk melakukan tugas ini. Misi adalah suatu pekerjaan besar, yang tidak akan mampu dilakukan seorang diri. Mengasihi dan memiliki kecintaan besar untuk bermisi tidak cukup. Perlu adanya ketrampilan dan kepemimpinan organisasi, perencanaan dan komunikasi. ${ }^{217}$

${ }^{216}$ Christian A Schwars, Pertumbuhan Gereja Secara Alamiah (Jakarta: Metanoia Publishing, 2005), 90 .

${ }^{217}$ Mays, Bagaimana Menjalankan Tim Kepemimpinan Misi Yang Efektif Di Gereja Anda. 


\section{DAFTAR PUSTAKA}

Alfons, Daud, Pandie Nidia, and Lina Ardela. "URGENSI PENGINJILAN SEBAGAI TANGGUNG JAWAB GEREJA." APOLONIUS : Jurnal Teologi Dan Pendidikan Kristen, 2020.

Alkitab Hidup Berkelimpahan Life Application Study Bible. Malang: Gandum Mas, 2016.

Ambarita, Darsono. Perspektif Misi Dalam Perjanjian Lama Dan Perjanjian Baru. Medan: Pelita Kebenaran Press, 2018.

Arifianto, Yonatan Alex, and Asih sumiwi Rachmani. "Peran Roh Kudus Dalam Menuntun Orang Percaya Kepada Seluruh Kebenaran Berdasarkan Yohanes 16 : 13.” Jurnal Diegesis 3, no. 1 (2020): 1-12.

Borthwick, Paul. Pemberitaan Injil, Tugas Siapa ? Bandung: Yayasan Kalam Hidup, 1987.

Bosch, David J. Tranformasi Misi Kristen. Jakarta: BPK Gunung Mulia, 1998.

-_—. Transformasi Misi Kristen. Jakarta: BPK Gunung Mulia, 1997.

Bradley, Zach. The Sending Church Defined. Knoxville: Upstream Collective, 2015.

Budiman, R. Surat-Surat Pastoral I Dan II Timotius Dan Titus. Jakarta: BPK Gunung Mulia, 2008. Chapman, Adina. Pengantar Perjanjian Baru. Bandung: Yayasan Kalam Hidup, 1980.

David, Taylor. Internationalizing of Missionaries. Grand Rapids: Baker Book House, 1991.

Donald, Senio. The Foundations for Mission in Teh New Testament. Maryknoll, New York: Orbis Books, 1983.

Eckhard J. Schnabel. Paul The Missionary. Downers Grove: InterVarsity, 2008.

Eims, LeRoy. Pemuridan Seni Yang Hilang. Bandung: Lembaga Literatur Baptis, 2002.

Everest, Don. Go and Do. Jakarta: Literatur Perkantas, 2012.

Henry, and Richard Blackaby. Kepemimpinan Rohani. Batam: Gospel Press, 2005.

Hutagalung, Patrecia. "Pemuridan Sebagai Mandat Misi Menurut Matius 28:18-20." Pengarah: Jurnal Teologi Kristen, 2020. https://doi.org/10.36270/pengarah.v2i1.22.

Hutahaean, Tumpal H. “Signifikansi Apologetika Dalam Penginjilan.” STULOS, 2019.

Indonesia, Bilangan Research. Survey Amanat Agung : Sudahkah Memudar? Jakarta: Yayasan Bilangan Research Center, 2019.

IPN, Tim. Blessed To Be A Blessing Course. Jakarta: Indonesian People Network, 2009. Jenson, Ron, and Jim. Stevens. Dinamika Pertumbuhan Gereja. Malang: gandum mas, 2004. Johny, The. Menjadi Pemimpin Unggul Dengan Strategi Marketing Paulus. Yogyakarta: ANDI, 2006.

Kane, J. Herbert. Christian Missions in Biblical Perspective. Grand Rapids: Baker Book House, 1976.

Keller, Marie Noël. Priscilla and Aquila: Paul's Coworkers in Christ Jesus. Collegeville: Liturgical Press, 2010.

Leech, Marvin. Pemuridan. Global Mission Center, 1997.

Manurung, Kosma. "Efektivitas Misi Penginjilan Dalam Meningkatkan Pertumbuhan Gereja." DUNAMIS: Jurnal Teologi Dan Pendidikan Kristiani 4, no. 2 (2020): 225-33. https://doi.org/10.30648/dun.v4i2.242.

Mays, David. Bagaimana Membuat Jemaat Anda Terlibat Dalam Misi Penginjilan. Peachtree City: ACMC, 1997.

-_- Bagaimana Menjalankan Tim Kepemimpinan Misi Yang Efektif Di Gereja Anda. Peachtree City: ACMC, 1996.

Meyers, Carol. Women in Scripture. Michigan: Eerdmans Publisihing Company, 2000. 
Munthe, Eben. "Mengoptimalkan Karunia Dalam Jemaat Untuk Melakukan Misi Amanat Agung Di Era 4.0." EPIGRAPHE: Jurnal Teologi Dan Pelayanan Kristiani, 2019.

https://doi.org/10.33991/epigraphe.v3i2.127.

Ollrog, and Wolf Henning. Paulus Und Seine Mitarbeiter. Neukirchen-Vluyn: Neukirchener Verlag, 1979.

Peters, George W. A Biblical Theology of Missions. Malang: Gandum Mas, 2006.

Pirolo, Neal. 8 Kiat Jitu Pendukung Misionaris Profesional. Jakarta: OM Indonesia, 1997.

Pritz, Ronald. Kepemimpinan Kristen. Yogyakarta: STII, n.d.

Rinawaty, Hannas. "Menerapkan Model Penginjilan Pada Masa Kini." Kurios (Jurnal Teologi Dan Pendidikan Agama Kristen), 2019.

Sanders, J. Oswald. Kepemimpinan Rohani. Bandung: Yayasan Kalam Hidup, 1993.

Schnabel, Eckhard J. Rasul Paulus Sang Misionaris: Perjalanan, Strategi, Dan Metode Misi Rasul Paulus. ANDI: Yogyakarta, 2008.

Schwars, Christian A. Pertumbuhan Gereja Secara Alamiah. Jakarta: Metanoia Publishing, 2005.

Setiawan, David Eko. "Dampak Injil Bagi Transformasi Spiritual Dan Sosial." BIA': Jurnal Teologi Dan Pendidikan Kristen Kontekstual 2, no. 1 (2019): 83-93.

Stephanus, Djuwansah Suhendro P. “Mengajarkan Penginjilan Sebagai Gaya Hidup Orang Percaya." Redominate, 2019.

Tambunan, Fernando. "Tantangan Misi Dalam Prespektif Pemikiran Era Postmodern.” In Seminar Mission Today, 2017. https://doi.org/10.1017/CB09781107415324.004.

Tenney, Merril C. Survei Perjanjian Baru. Malang: Gandum Mas, 2009.

Tomatala, Yakob. Penginjilan Masa Kini 2. Malang: Gandum Mas, 2018.

-__. Teologi Misi. Jakarta: YT Leadership Foundation, 2003.

Tong, Stephen. Teologi Penginjilan. Surabaya: Momentum, 2004.

Warren, Rick. Pertumbuhan Gereja Masa Kini. Malang: Gandum Mas, 1999.

Wellem, F. D. Riwayat Hidup Singkat Tokoh-Toko. Jakarta: BPK Gunung Mulia, 2003.

Wells, Tom. A Vision for Mission. Carlisle: Banner of Truth, 1985.

Wiebracht, Dean. Menjawab Tantangan Amanat Agung. Yogyakarta: Andi Offset, 2008.

Wilis, Avery T. Indonesia Revival. Bandung: Lembaga Literatur Baptis, 1977.

William, MacDonald. Penginjilan Pribadi, Buku 1 Dari Seri: Pedoman-Pedoman Praktis Bagi Orang Kristen. Jakarta: Sastra Hidup Indonesia, 2013.

Zaluchu, Sonny Eli. "Strategi Penelitian Kualitatif Dan Kuantitatif Di Dalam Penelitian Agama." Evangelikal: Jurnal Teologi Injili Dan Pembinaan Warga Jemaat, 2020. https://doi.org/10.46445/ejti.v4i1.167.

Tentang penulis:

Christian Bayu Prakoso, mahasiswa di Sekolah Tinggi Teologi Baptis Indonesia, dapat dihubungi di: christianbayu@stbi.ac.id.

Yonatan Alex Arifianto, mengajar di Sekolah Tinggi Teologi Sangkakala, Salatiga. Dapat dihubungi di: arifianto.alex@sttsangkakala.ac.id. 